UDC 338.91:5(51) (091)

Submitted: 16.09 .18

LBC 66.09(5Кит)

Accepted: 25.11 .18

\title{
PROBLEMS OF UNEVEN DEVELOPMENT OF CHINA IN THE WORKS OF CHINESE AREA STUDIES SCHOLARS ${ }^{1}$
}

\author{
Svetlana B. Makeeva \\ Irkutsk State University, Irkutsk, Russian Federation
}

\begin{abstract}
Introduction. Based on the analysis of Chinese scholars' works in the field of area studies, such problem as the uneven development of the territory of China has been identified. Intense social and economic transformations in China at the end of the $20^{\text {th }}$ century influenced the emergence of regional problems, the solution of which was possible only through the competent regional policy of the Chinese leadership. As part of the study of regional disproportionality, Chinese researchers highlight the characteristic features inherent in each of the provinces and autonomous regions of the Northeast, North, East, Central South, South West and North West regions of China. These research are based on the study of economic agglomeration, regional division and features of regional management. Methods. On the basis of the method of logical analysis, the features of the formation of regional knowledge in China within the framework of borrowing the theoretical and methodological base of Western European and American science of the region have been determined. The use of a systematic approach in the analysis of Chinese-language scientific literature revealed one of the key problems in the field of national regional studies of China, namely the problem of uneven regional development of China. Analysis. Analysis of Chinese-language scientific literature allows the author to identify four main groups of reasons: geographical, historical, cultural, economic, underlying the disproportionate regional development of China. The author analyzes scientific articles and monographs of leading Chinese scholars published not only in China, but also in the United States. The works of Chinese authors Bao Yuan, Wang Xuanxuan, Wei Yehua, Li Zhuni, Luo Yu, Lu Zunhua, Wu Peng, Hu Zhaoliang, Zhang Wei, Chiang Lexiang contain a comprehensive analysis of the imbalance of the socioeconomic development of China's regions. Results. Results of this paper can be summarized in the following points: the study of the causes of uneven development of the territory of China will allow to more objectively perceive the origins of modern domestic regional problems in China and identify the features of the use of the results of scientific work of Chinese scientists in the formation of regional policy to eliminate socio-economic disproportion in the development of China.

Key words: China, area studies, uneven development of the territory of China, Chinese scholars, regional processes, disproportion, history of science about the region.
\end{abstract}

Citation. Makeeva S.B. Problems of Uneven Development of China in the Works of Chinese Area Studies Scholars. Vestnik Volgogradskogo gosudarstvennogo universiteta. Seriya 4, Istoriya. Regionovedenie. Mezhdunarodnye otnosheniya [Science Journal of Volgograd State University. History. Area Studies. International Relations], 2019, vol. 24, no. 1, pp. 225-236. (in Russian). DOI: https://doi.org/10.15688/jvolsu4.2019.1.20

УДК 338.91:5(51) (091)

Дата поступления статьи: 16.09 .18

Дата принятия статьи: 25.11.18

ББК 66.09(5Кит)

ПРОБЛЕМЫ НЕРАВНОМЕРНОГО РАЗВИТИЯ КИТАЯ В РАБОТАХ КИТАЙСКИХ УЧЕНЫХ-РЕГИОНОВЕДОВ ${ }^{1}$

\author{
Светлана Борисовна Макеева
}

Иркутский государственный университет, г. Иркутск, Российская Федерация 
Аннотация. На основе анализа работ китайских ученых в области регионоведческих исследований была выделена такая основная проблема в сфере национального регионоведения Китая, как неравномерное развитие территории КНР. Бурные социально-экономические преобразования в КНР в конце ХХ в. повлияли на возникновение региональных проблем, решение которых возможно было лишь при грамотной региональной политике китайского руководства, опирающегося на регионоведческие исследования китайских ученых. В рамках изучения региональной диспропорциональности китайские исследователи выделяют характерные черты, присущие каждой из провинций и автономных районов Северо-Восточного, Северного, Восточного, Центрально-Южного, Юго-Западного и Северо-Западного районов КНР. Эти исследования базируются на изучении экономической агломерации, регионального деления и особенностей регионального управления. Анализ китаеязычной научной литературы позволяет автору выделить четыре основные группы причин, лежащих в основе диспропорционального регионального развития Китая: географические, исторические, культурные, экономические. Автор анализирует научные статьи и монографии ведущих китайских ученых, изданных не только на территории КНР, но и в США. Работы китайских авторов Бао Юаня, Ван Сюаньсюаня, Вэй Ехуа, Ли Чжуни, Ло Ю, Лу Цзуньхуа, У Пэна, Ху Чжаоляна, Чжан Вэя, Чян Лэсяна содержат комплексный анализ проблемы дисбаланса социально-экономического развития регионов Китая. Исследование причин неравномерного развития территории Китая позволит более объективно воспринимать истоки современных внутренних региональных проблем в КНР и выявить особенности использования результатов научной деятельности китайских ученых в рамках формирования региональной политики по ликвидации социально-экономической диспропорциональности в развитии Китая.

Ключевые слова: Китай, регионоведческие исследования, неравномерное развитие территории Китая, китайские ученые, региональные процессы, диспропорциональность, история науки о регионе.

Цитирование. Макеева С. Б. Проблемы неравномерного развития Китая в работах китайских ученых-регионоведов // Вестник Волгоградского государственного университета. Серия 4, История. Регионоведение. Международные отношения. - 2019. - Т. 24, № 1. - C. 225-236. - DOI: https://doi.org/10.15688/jvolsu4.2019.1.20

Введение. Регионоведческие исследования в Китае затрагивают проблемы регионального социально-политического, экономического развития всей территории Китайской Народной Республики. Начиная с политики реформ и открытости, проводимой Дэн Сяопином с 1978 г., китайское общество, внедряя рыночные отношения в социалистическую модель экономики, начало заимствовать западноевропейские и американские научные теории о регионе. В 1980-егг. на китайский язык были переведены работы ученых У. Айзарда [23], А. Вебера [3], С. Денисона [22], Н. Калдора [24], В. Лаунхардта [29], А. Лёша [6], В. Кристаллера [21]. Китайские исследователи при анализе региональных процессов в различных районах Китая использовали западноевропейский и американский научный опыт. Бурные социально-экономические преобразования в КНР в конце XX в. повлияли на возникновение региональных проблем, решение которых возможно было лишь при грамотной региональной политике китайского руководства, опирающегося на регионоведческие исследования китайских ученых. В рамках национального регионоведения одной из ключевых внутренних региональных проблем, обо- стрившейся в 1990-е гг., является проблема дисбаланса социально-экономического развития регионов Китая, решение которой находит отражение в работах таких китайских ученых, как Бао Юань [1], Ван Сюаньсюань [2], Вэй Ехуа [26], Ли Чжуни [7], Ло Ю [8], Лу Цзуньхуа [9], У Пэн [12], Ху Чжаолян [14], Чжан Вэй [15], Чян Лэсян [17].

Анализ работ китайских ученых по региональным проблемам исследования является актуальным, так как, с одной стороны, современный Китай демонстрирует мировому сообществу беспрецедентный по продолжительности экономический рост, сопровождающийся социальными преобразованиями и построением социально ориентированной экономики; с другой стороны, в китайском обществе все еще сохраняются такие региональные проблемы, как разница в социально-экономическом развитии между городом и деревней, а также неравномерное социально-экономическое развитие северо-западных, северо-восточных, восточных и южных провинций. Актуальность исследования данных проблем внутреннего регионального развития Китая подтверждает и пристальное внимание к этим процессам со стороны китайского руководя- 
щего аппарата власти. Задачи, поставленные китайским правительством на XIX съезде КПК осенью 2017 г., определяют перспективы решения внутренних региональных проблем китайского общества. Особое значение в сложившихся условиях отводится использованию научно-практических исследований китайских ученых, ориентированных на прагматический результат в изучении региональных процессов, входящих в спектр регионоведческой проблематики.

Выявление основных проблем регионального развития, относящихся к научной тематике национального регионоведения Китая, а также анализ работ китайских ученых по регионоведческим проблемам исследования позволит определить неравномерное развитие территории КНР как одну из основных региональных проблем в Китае, а также выявить причины диспропорциональности и проследить особенности формирования собственной научно-прагматической базы регионоведческих исследований в китайском научном сообществе. Основной целью данной работы является освещение позиции китайских ученых в области регионоведения о причинах неравномерного развития регионов КНР на основе анализа современной китаеязычной научной литературы. В Китае регионоведческие проблемы исследования имеют не только научно-теоретический характер, но и нацелены на прагматический результат. На территории КНР осуществляют свою деятельность свыше 35 научных институтов, занимающихся исследованиями региональных проблем, а также проблем, связанных с межрегиональным взаимодействием [5, с. 157-235].

Методы. В представленном исследовании на основе использования метода логического анализа были определены особенности формирования регионоведческих знаний в Китае в рамках заимствования теоретико-методологической базы западноевропейской и американской науки о регионе. Выделены ключевые работы таких китайских ученых, как Ян Кайчжун, Да Чжанчао, Чэнь Цзунсин, в области определения базовой теоретической составляющей регионоведческих исследований в Китае. Применение системного подхода при анализе китаеязычной научной литературы позволило выявить одну из ключевых проблем в области национального регионоведения Китая, а именно проблему неравномерного регионального развития территории Китая. В результате использования сравнительно-исторического метода были выделены четыре группы работ китайских ученых по причинам неравномерного развития Китая. К первой группе можно отнести научные исследования Вэй Ехуа, У Пэна, Ху Чжаоляна, Чян Лэсяна, которые утверждают, что природно-географические условия выступают в качестве причины неравномерного регионального развития Китая. Во вторую группу исследований китайских ученых входят работы Бао Юаня, Ли Чжуни, Сю Юйчина. Данные авторы считают, что в основе неравномерности регионального развития лежат исторические условия эволюции Китая. Научные работы китайских авторов Чжан Вэя и Ван Сюаньсюаня составляют третью группу исследований, в рамках которой первостепенно положение о том, что культурные особенности развития каждого района Китая повлияли на последующее неравномерное развитие всей территории КНР. В четвертую группу входит большинство китайских исследователей, которые утверждают, что экономические причины являются основными в процессе неравномерного развития территории Китая. К данной группе относятся работы таких китайских авторов, как Ло Ю, Лу Цзуньхуа, Ма Чунмин, Сюе Чан, Хэ Чин, Ши Цзеньпин.

Историография причин неравномерного регионального развития Китая является объектом проводимого автором исследования. Необходимо отметить, что китайская историография, по причинам диспропорциональности в развитии Китая ранее в отечественных политологических исследованиях не была представлена. Хотя она, безусловно, заслуживает особого внимания при проведении комплексных, трансдисциплинарных, регионологических, регионоведческих и политологических исследований эволюции региональной политики Китая по отношению к такой актуальной проблеме, как неравномерное региональное развитие территории КНР.

Анализ. Быстрые темпы социально-экономического развития КНР с конца ХХ в., участие Китая в выстраивании международных отношений на основе экономической дипломатии - все это определило потребность 
страны в проведении собственных научнопрагматических исследований, нацеленных на изучение различных процессов регионального развития, происходящих на территории Китая. С конца 1970-х гг. многие региональные изменения в КНР, относящиеся к регионоведческой тематике, были связаны с научным обоснованием внедрения рыночных отношений в социалистическую модель экономики, определением необходимости построения «социализма с китайской спецификой». Это было вызвано, с одной стороны, потребностью в повышении темпов роста экономического развития, продуктивном распределении территориально-производственных комплексов, а с другой - выявлением последствий экономического прогресса в виде возникновения новых региональных проблем. Научные исследования Китая, связанные с регионоведческой проблематикой, стали одним из элементов государственной региональной политики, так как именно такие исследования определяют приоритеты в социально-экономическом развитии территории КНР, и на основании этого формируется наиболее оптимальный план развития всех регионов страны. Одной из особенностей научно-исследовательской деятельности в Китае в области регионоведческой проблематики является ориентация на западноевропейскую и американскую научнотеоретическую базу регионоведческих исследований и адаптация этих наработок под уникальную действительность региональных процессов в Китае, прагматическая направленность, связанная с обязательным применением научно-теоретических наработок на практике при решении региональных проблем.

Основной региональной проблемой, относящейся к тематике национального регионоведения Китая, является проблема дисбаланса внутреннего регионального развития территории КНР. Анализируя особенности эволюции китайского общества со второй половины XX в., необходимо отметить, что данная проблема обострилась после проведения политики реформ и открытости в 1970-80-е гг., что отразилось на возникновении диспропорций в социально-экономическом развитии между городом и деревней, между восточными, южными районами - с одной стороны - и северо-западными, северо-восточными - с дру- гой. Актуальность регионоведческих исследований дисбаланса социально-экономического развития регионов Китая была определена в 1982 г. одним из ведущих китайских ученых экономистов Ху Чжаоляном, специализирующимся на исследовании географии городов и городском планировании, изучении процессов регионального развития Китая [14]. Ху Чжаолян утверждал, что исследования диспропорциональности регионального развития КНР являются исторической задачей отечественной китайской науки $[13$, с. 90$]$.

В рамках научного обоснования причин дисбаланса регионального развития территории КНР китайские ученые в первую очередь обращались к опыту западноевропейских и американских исследователей в области регионоведческой проблематики. Это было вызвано тем, что внедрение рыночных отношений в социалистическую модель экономики Китая порождало новые процессы в региональном развитии Китая, объяснить которые, по мнению китайских ученых, возможно было только при условии изучения научно-теоретического опыта исследования региональных процессов в тех странах, где рыночная экономика была уже довольно развита. В 1991 г. китайский исследователь Да Чжанчао издает книгу «Теория региональной науки» [4], а Чэнь Цзунсин опубликовывает работу «Введение в региональную науку». Данные произведения являлись переводом работы американского исследователя, основоположника науки о регионе Уолтера Айзарда «Introduction to regional science» [16]. Научно-теоретические положения У. Айзарда базировались на обосновании ключевых положений новой науки о регионе, которая интерпретировала влияние рыночной экономики на процессы регионального развития. Помимо работ У. Айзарда, китайские ученые обращались к произведениям таких западноевропейских ученых специалистов в области регионоведческой тематики, как А. Вебер [3], С. Денисон [22], Н. Калдор [24], В. Лаунхардт [25], А. Лёш [6], В. Кристаллер [21]. Использование научнотеоретических достижений западноевропейских и американских исследователей в разработке регионоведческой тематики в условиях анализа причин дисбаланса регионального развития территории Китая повлияло на ком- 
плексный анализ регионального пространства КНР и изучение последствий внедрения рыночных отношений в социалистическую модель экономики КНР.

Следующим этапом в изучении регионоведческих проблем исследования китайскими учеными было использование теоретикометодологической базы западноевропейской и американской науки о регионе в выделении основных причин дисбаланса внутреннего регионального развития Китая. Китайские ученые в рамках определения причин региональной диспропорциональности выделяют характерные черты, присущие каждой из провинций и автономных районов Северо-Восточного, Северного, Восточного, Центрально-Южного, Юго-Западного и Северо-Западного районов КНР. Эти исследования базируются на изучении экономической агломерации, регионального деления и основ регионального управления. Анализ китаеязычных работ позволяет выделить несколько причин, повлиявших на возникновение диспропорциональности в региональном развитии Китая.

К первой группе китайских исследователей, которые считают, что природно-географическое положение каждой в отдельности провинции и автономного района оказывает прямое влияние на усиление диспропорциональности в социально-экономическом развитии районов Китая, относятся Ван Сюаньсюань [2], Вэй Ехуа [28], У Пэн [12], Ху Чжаолян [13], Чян Лэсян [17]. Ху Чжаолян в одной из своих работ «Характеристики влияния географического положения» отмечает, что важным фактором, ограничивающим развитие региона, является географическое положение, так как природноклиматические особенности определяют базовые элементы в структуре региона [14, c. 25]. В работах Вэй Ехуа пространственное различие, а точнее различие в географическом положении, также является одной из главных причин неравномерного регионального развития [27; 29].

Анализируя географический фактор в развитии дисбаланса регионального развития Китая, некоторые исследователи используют научные методы и подходы географии для выявления зависимости социально-экономического развития регионов от физико-географического положения. Так, например, У Пэн в своей работе «Идея всеобщего благосостояния и неравномерное развитие регионов Китая», применяя метод географического районирования, выявил отдельные неравномерные зоны в рамках Восточного, Центрального, Западного и Северно-Восточного регионов Китая. У Пэн считает: «Некоторые отстающие провинции восточного побережья за счет своего географического положения и природных ресурсов использовали свой шанс после проведения реформ и осуществили скачок в развитии, быстро достигли и превзошли средний уровень государства» [12, с. 10]. Географический фактор в качестве базовой основы диспропорциональности в развитии регионов Китая выделял такой исследователь, как Чян Лэсян, в работе «Влияние географической среды на социально-экономическое развитие». Опираясь на системный подход, указанный автор проанализировал влияние географического положения на развитие отдельной территории на примере городского округа Ляочэн в провинции Шаньдун. Чян Лэсян пришел к выводу, что географическая среда как совокупность природных условий определяет прежде всего развитость транспортной инфраструктуры. Все элементы географической среды отдельной территории в совокупности и каждый в отдельности оказывают влияние на экономическое развитие региона [17, с. 63]. Другой китайский исследователь Ван Сюаньсюань в работе «Анализ причин неравенства в экономическом развитии четырех регионов Китая» рассматривал природный фактор, а именно различие природной основы, не как отдельный элемент, а как составляющую системы, группу факторов неравенства регионального развития Китая. По мнению Ван Сюаньсюаня, природная среда регионов, наличие ресурсов и условия местоположения являются ключевыми показателями дисбаланса регионального развития. «Восточный регион Китая, - пишет исследователь, - во всем превосходит Центральный, Западный и Северо-Восточный регионы» [2, с. 131].

Таким образом, ряд китайских исследователей выявляют причины диспропорциональности регионального развития Китая в рамках изучения физико-географического положения отдельных районов КНР, утверждая, что физико-географическое положение провин- 
ций, автономных районов оказывает прямое влияние на неравномерное развитие районов КНР, порождая отсталость в развитии транспортной инфраструктуры, устанавливая ограничения в возможности участия отдельных административно-территориальных единиц в общих проектах в рамках социально-экономического развития КНР. В основном исследователи не только констатируют и подтверждают факт существования данной проблемы, но и определяют дальнейший процесс формирования региональной политики КНР с учетом наличия физико-географических условий диспропорциональности.

Ко второй группе китайских авторов, которые считают, что исторические условия лежат в основе неравномерного регионального развития территории Китая, относятся Бао Юань [1], Ли Чжуни [7], Сю Юйчин [11]. По их мнению, диспропорциональность как региональное явление сложилась исторически, и проявление зачатков дисбаланса регионального развития связано с последствиями «опиумных войн», прошедших в Китае в середине XIX века. Результаты своих исследований данные китайские ученые публикуют на страницах таких исторических журналов, как «Historical Research»(《历史研究》), 《Chinese Social History Review》(《中国社会历史评论》), «History» (《看历史》), «Historical Geography» (《历史地理》). Бао Юань в своей работе «Причины дисбаланса в экономическом развитии регионов Китая и контрмеры» пишет о том, что неравенство в региональном развитии образовалось не за короткий промежуток времени, это был длительный исторический процесс [1, с. 111]. Экономический дисбаланс стал проявляться в династию Мин, а во времена Цин он стал наиболее отчетлив. После «опиумных войн» в начале 1840 -х, а затем во второй половине 1850-х гг. Китай превратился в полуфеодальное полуколониальное государство, став, по сути, источником ресурсов и рынком для стран Европы. Инвестиции европейских стран главным образом концентрировались в Восточном районе страны, активно строились различные предприятия и фабрики, а Центральный и Западный районы подверглись более жесткому захвату и разорению, поэтому уровень экономического развития был очень слабым. Аналогичную точку зрения высказывает и другой китайский исследователь Ли Чжуни в своей работе «Анализ причин неравного экономического развития Китая». Он утверждает, что неравенство в экономическом развитии возникло и усилилось с 1840 по 1949 г., то есть в период после «опиумных войн» и до основания КНР. Капиталистические инвестиции и управление в основном были сосредоточены в восточных прибрежных городах, что привело к аномальному распределению производительных сил в Восточном и Западном регионах, закладывая тем самым основу для диспропорции в экономическом развитии Китая [7, с. 121]. Данная точка зрения, согласно которой неравномерность социально-экономического развития регионов Китая сложилась исторически еще в XIX в., находит отражение в совместной работе Сю Юйчина и Ли Шуанчэна «Динамичный анализ неравного экономического развития в трех регионах Китая» [11], а также в общем труде Шэн Сунчэна и Ши Чюньхуа «Анализ тенденции изменения в уровнях экономического развития регионов» [18]. В данных произведениях китайские исследователи, используя исторический подход, выделяют особенности эволюции такой основной региональной проблемы Китая, как диспропорциональность [11, с. 87]. Они утверждают, что такие события в историческом процессе Китая, как «опиумные войны», изменили ход регионального развития территории Китая, заложив неравные условия в социально-экономических региональных изменениях.

Анализ китаеязычной литературы показывает, что китайские исследователи связывают процессы усиления дисбаланса в региональном развитии Китая с такими историческими событиями, как реформы Дэн Сяопина, проводимые с 1978 года. По утверждению китайского исследователя Ян Юйяна, после проведения «политики реформ и открытости» в научных китайских кругах начинают проводить исследования проблемы экономического регионального дисбаланса КНР [19, с. 563]. Такие китайские ученые, как Бао Юань, Цзие Юньпхин, Ду Сюйюй, отмечают, что стратегия быстрого экономического роста, разработанная Дэн Сяопином и заключавшаяся в «обогащении одних районов, которые потом помогут остальным», дала хороший толчок к прогрессу экономически развитых 
районов Китая. Быстрый социально-экономический рост наблюдался в прибрежных районах, это в основном восточные и юго-восточные провинции, но при этом провинции Центрального и Западного Китая стали отставать по социально-экономическим показателям. По утверждению данных исследователей именно реформы Дэн Сяопина оказали существенное влияние на усиление диспропорциональности регионального развития Китая. В работах китайских ученых, определяющих в качестве причины неравномерного регионального развития исторические условия, содержится анализ таких основных событий в истории Китая, как «опиумные войны» XIX в. и реформы Дэн Сяопина XX века. Китайские исследователи комплексно анализируют влияние данных исторических событий на возникновение неравномерности, а также прослеживают эволюцию диспропорциональности в дальнейшем [1].

Анализ китаеязычной литературы по регионоведческим проблемам исследования показывает, что среди китайских авторов есть сторонники рассмотрения влияния культурных факторов на неравномерное развитие отдельных районов Китая. Широкое применение в регионоведческих исследованиях Китая получил культурологический подход, который использовался при изучении территориальных особенностей регионального развития китайского многонационального государства. На страницах научных журналов Китая «The Border Economy and Culture» (《边疆经济与文化》), 《Cross-Cultural Management》(《跨文化管理》), 《Local Culture Research Journal» (《地方文化研究辑刊》), «Journal of Original Ecological National Culture» (《原生态民族文化学刊》) размещены статьи, выдержки из монографий, посвященные рассмотрению влияния культуры на развитие территории Китая.

Чжан Вэй в своей работе «Анализ влияния культуры региона на его экономическое развитие», опираясь на точку зрения американского ученого Эдуарда Банфилда [20] о влиянии культуры на экономику, рассмотрел данный феномен на примере культурных различий в Восточном, Центральном и Западном регионах Китая. Он утверждает, что посредством своей интегративной функции культура оказывает влияние на развитие социума и экономики, образует фон экономического развития, является составляю- щим элементом в циркуляционной модели экономики и важным фактором, стимулирующим экономическое развитие региона. Далее автор при помощи компаративного анализа сравнивает культуры трех регионов, выявляя их особенности. Чжан Вэй отмечает, что культура каждого из регионов складывалась в течение нескольких тысяч лет. Культуру Восточного региона Чжан Вэй определил как слияние традиционной китайской и иностранной культур и отметил, что она порождает такие характерные черты, как рискованность, инициативность, новаторство и т. д. Культуру Центрального Китая он описал как отсталую, консервативную, инертную и пассивную, ядро которой составляет конфуцианство. Главные особенности Чжан Вэй выделил в следующих постулатах: 1) «ставить земледелие превыше всего, а торговле отдавать второстепенное место»; 2) «ценить справедливость, пренебрегая выгодами»; 3) «придерживаться золотой середины»; 4) «довольствоваться тем, что есть» $[15$, с. 292]. Как считает Чжан Вэй, культура Центрального региона Китая в какой-то степени сдерживала экономический рост данной территории на протяжении длительного исторического периода, тем самым закладывая основу диспропорциональности в будущем. В Западном регионе земледелие и скотоводство издавна занимали главенствующее положение, поэтому торговое мышление у населения развито слабо. Большую роль в жизни людей играет вера. По мнению Чжан Вэя, очень многие в данном регионе по-прежнему остаются набожными, к концепции рыночной экономики и научно-техническому прогрессу относятся крайне противоречиво [15].

Определяющее влияние культурных факторов на социально-экономическое развитие отдельных регионов в Китае рассматривал китайский исследователь Ван Сюаньсюань. Он утверждал, что идеология и культура выступают одним из главных факторов, влияющих на экономическое развитие регионов страны. В своих работах Ван Сюаньсюань, отмечает, что консервативная отсталость идеологической концепции является важной причиной того, что экономическая жизнеспособность в Центральном и Западном регионах, особенно в Западном регионе, недостаточно развита и экономическое развитие явно ограничено. Кроме того, практически все нацменьшинства Китая 
проживают в провинциях и автономных районах Западного региона. С целью предотвращения национальных конфликтов государство старается не вмешиваться в культуру и быт нацменьшинств, что, в свою очередь, ограничивает правительство в проведении кардинальных экономических преобразований в этом регионе. Конституция КНР гласит, что государство при освоении ресурсов и строительстве предприятий в национальном автономном районе должно учитывать его интересы. Именно поэтому Ван Сюаньсюань считает идеологию и культуру одной из причин экономической отсталости Западного региона Китая [2, с. 131].

Анализ китаеязычных работ, определяющих зависимость неравномерности регионального развития от культурных территориальных особенностей, показывает, что в основном авторы отмечают важность проведения последовательной культурной региональной политики, стабилизирующей ситуацию в Западном регионе Китая.

Рассматривая причины неравномерного развития регионов Китая, необходимо отметить, что центральное место занимают экономические факторы диспропорциональности. Анализ монографий ведущих китайских исследователей в области экономико-регионального анализа Китая Ло Ю, Хэ Чина, Сюе Чана [8], Лу Цзуньхуа, Ма Чунмина, Ши Цзеньпин [9], У Пэна, Хэ Чина [12], Чжан Вэя, Ли Сяояна, Чжоу Чжэньхуа [15], изучение научных статей на страницах таких журналов, как «Energy of China», «Comprehensive Transportation», «Macroeconomics», «Economic Research Journal», «China Industrial Economics», «China Rural Survey», «China Economist», «Statistical Research», «Chinese Rural Economy», показывает значимость экономической составляющей в регионоведческих исследованиях в Китае.

Выделяя экономический фактор как главную причину неравномерного регионального развития, китайские ученые применяют в своих трудах различные научные методы и подходы. Исследователи в области экономики Китая У Пэн и Хэ Чин в своей работе «Идея всеобщего благосостояния и неравномерное развитие регионов Китая», используя экономико-статистический метод, анализирует период развития экономики КНР с 1978 по
2009 год. Основным источником исследования выступает «Сборник статистических данных КНР за 60 лет». У Пэн, анализируя экономическое развитие отдельно взятых районов Китая через экономико-статистический анализ административных единиц КНР, утверждает, что экономические факторы развития отдельных районов Китая являются определяющими в дисбалансе регионального пространства. Экономико-статистические данные выявляют несоответствие в развитии отдельных административных районов КНР по показателям экономического роста в первичном, вторичном и третичном секторах экономики [12, с. 11].

Ли Сяоянь, Чжан Вэй, Чжоу Чжэньхуа анализируют причины неравномерного регионального развития Китая при помощи использования экономико-статистического метода. Данные авторы, применяя систему показателей развития каждой административно-территориальной единицы КНР, характеризующей через цифры уровень развития экономических явлений и процессов, выявляют в качестве основной причины диспропорциональности в Китае разные показатели в экономическом развитии отдельных районов [15]. В совместной работе «Динамический анализ экономического неравенства регионов Китая» китайские авторы Лу Цзуньхуа, Ма Чунмин, Ши Цзеньпин на основе применения экономикостатистического анализа приводят мониторинг диспропорциональных процессов в региональном развитии КНР с конца XX по начало XXI века. В своем исследовании авторы опирались на такие показатели экономико-регионального развития отдельных районов КНР, как состояние природно-ресурсной базы и особенности ее использования, производство различных групп товаров, объемы инвестиций в различные секторы экономики района, уровень функционирования финансовой системы, основные направления внешнеэкономических связей, товарные экспортно-импортные операции $[9$, с. 4$]$.

В рамках определения экономической причины в качестве основной в неравномерном региональном развитии Китая такие ученые, как Ло Ю, Хэ Чин и Сюе Чан, использовали метод установления причинно-следственных связей, а именно метод сопутствующих 
изменений. В своей совместной работе «Влияние уровня законности на экономическое развитие Китая» авторы выдвинули гипотезу о взаимозависимости уровня экономического развития региона от уровня законопорядка. Они выяснили, что «повышение уровня законоисполнения не только стимулирует банковское кредитование, но и содействует развитию рынка капиталов и повышению финансовых показателей рынка» [8, с. 119]. В данной работе авторы опирались на исследования таких китайских экономистов, как Чжан Цзеньхуа и Ван Пэн, которые, «основываясь на исследовании данных каждого банка, обнаружили, что повышение уровня законности в значительной мере стимулирует увеличение объемов банковского кредитования», и это впоследствии оказывает позитивное влияние на инвестиционный климат в отдельно взятом районе КНР, что в дальнейшем определяет и экономический рост данного регионального пространства. Кроме того, Ло Ю, Хэ Чин и Сюе Чан применяют метод расчетов формульных единиц, который демонстрирует экономическое развитие не только по уровню современного состояния экономических показателей, но и в перспективе, на основе использования различных формул для расчета ВВП, степени маркетизации финансового сектора и выявления связи между показателями и уровнем законности. Экономический метод расчетов формульных единиц был применен Ми Цзюанем и Су Синюем в их совместной работе «Анализ факторов экономического роста в регионах, а также его различия». В данном исследовании, построенном исключительно на вычислительных формулах, авторы доказывают первостепенность факторов экономического роста в зарождении причин неравномерного развития отдельных районов Китая [10, с. 18].

Результаты. Проанализировав работы китайских ученых в области регионоведения, мы пришли к следующим выводам:

- на основе заимствования американских и западноевропейских теорий о регионе в Китае была сформирована собственная теоретико-методологическая база исследований в области регионоведческой проблематики, нацеленная на применение результатов научной деятельности при формировании региональной политики китайского правительства;
- анализ китаеязычной литературы в области регионоведческих исследований позволил выделить такую основную региональную проблему КНР, как неравномерное развитие территории Китая;

- нами было выделено четыре группы работ китайских ученых по причинам неравномерного развития Китая. Первая группа ученых считает, что в основе социально-экономической диспропорциональности лежат природно-географические факторы; вторая группа утверждает, что исторические условия повлияли на развитие неравномерности; третья группа ученых полагает, что культурные причины диспропорциональности самые основные; четвертая группа ученых называет социально-экономические причины ключевыми в развитии территориальной неравномерности;

- все работы китайских ученых отличаются системным анализом причин неравномерности территориального развития, применением целого комплекса научных методов, объективностью научных взглядов.

\section{ПРИМЕЧАНИЕ}

\begin{abstract}
${ }^{1}$ Исследование осуществляется при финансовой поддержке гранта РФФИ. Проект № 19-01100040 «История и методология регионоведческих исследований Азиатско-Тихоокеанского региона в русле современной трансдисциплинарной регионологии».
\end{abstract}

\section{СПИСОК ЛИТЕРАТУРЫ}

1. Бао Юань. Причины дисбаланса в экономическом развитии регионов Китая и контрмеры = 暴元. 中国区域经济发展不平衡的原因及对策 / 暴元. - 河南: 河南师范大学, 2008. - 186 页) (на кит. яз.) / Бао Юань. - Хэнань : Изд-во Хэнаньского педагогического университета, 2008. - 186 с.

2. Ван Сюаньсюань. Анализ причин неравенства в экономическом развитии четырех регионов Китая = 王选选.中国四大区域经济发展差距的成因分析 /王选选//财贸经济. - 2009. - 11 期. - 页 131137) (на кит. яз.) / Ван Сюаньсюань // Экономика финансов. - 2009. - № 11. - С. 131-137.

3. Вебер, А. Теория размещения промышленности / А. Вебер. - Л. ; М. : Книга, 1926. - 223 с.

4. Да Чжанчао. Теория региональной науки $=$ 大张超. 区域科学论 / 大张超. -上海 : 华东师范大学, 1991. - 159 页) (на кит. яз.) / Да 
Чжанчао. - Шанхай : Изд-во Восточно-китайского педагогического университета, 1991. - 159 с.

5. Комиссина, И. Н. Научные и аналитические центры Китая / И. Н. Комиссина - М. : РИСИ, 2012. -265 c.

6. Лёш, А. Пространственная организация хозяйства / А. Лёш. - М. : Наука, 2007. - 664 с.

7. Ли Чжуни. Анализ причин неравного экономического развития Китая = 李中一. 中国地区经济发展不平衡的原因分析 / 李中一 // 黑龙江史志. - 2009. - 18 期. - 页 121-122) (на кит. яз.) / Ли Чжуни // Исторические описания провинции Хэйлунцзян. - 2009. - № 18. - С. 121-122.

8. Ло Ю. Влияние уровня законности на экономическое развитие Китая=罗煜. 地区执法水平对 中国区域金融发展的影响 / 罗煜, 何青, 薛畅 // 经济研究. - 2016. - 7 期. - 页 119-124) (на кит. яз.) / Ло Ю, Хэ Чин, Сюе Чан // Экономические исследования. - 2016. - № 7. - С. 119-124.

9. Лу Цзуньхуа. Динамический анализ экономического неравенства регионов Китая=卢遵华. 中国地区经济差异的动态分析/卢遵华, 马崇明, 史建平 // 广东省经济管理干部学院学报. 2001. - 1 期. - 页 4-15) (на кит. яз.) / Лу Цзуньхуа, Ма Чунмин, Ши Цзеньпин // Вестник Гуандунского университета по управлению экономикой. - 2001. № 1. - С. 4-15.

10. Ми Цзюань. Анализ факторов экономического роста в регионах, а также его различия $=$ 米娟. 区域经济增长影响因素及差异性分析 / 米娟, 苏星宇 // 生产力研究. - 2012. - 9 期. - 页 18-22) (на кит. яз.) / Ми Цзюань, Су Синюй // Исследования производительных сил. - 2012. - № 9. - С. 18-22.

11. Сю Юйчин. Динамичный анализ неравного экономического развития в трех регионах Китая = 许月卿. 我国三大地带经济发展不平衡性动态 分析 / 许月卿, 李双成. - 北京: 北京大学. 144 页) (на кит. яз.) / Сю Юйчин, Ли Шуанчэн. - Пекин : Изд-во Пекинского университета, 2004. - 144 с.

12. У Пэн. Идея всеобщего благосостояния и неравномерное развитие регионов Китая = 武鹏. 共同富裕思想与中国地区发展差距 / 武鹏 // China Academic Journal Electronic Publishing House. - 2012. - 页 10-12) (на кит. яз.) / У Пэн, Хэ Чин. - Электрон. текстовые дан. - Режим доступа: http://www.doc88.com/p-904283055840.html (дата обращения: 21.06.2017). - Загл. с экрана.

13. Ху Чжаолян. Региональные исследования и разработки=胡兆量. 地域研究与开发 /胡兆量. 北京, 1985. - 97 页) (на кит. яз.) / Ху Чжаолян. - Пекин : Изд-во Пекинского университета, 1985. - 97 с.

14. Ху Чжаолян. Характеристики влияния географического положения $=$ 胡兆量. 地理位置的 特性及影响/胡兆量. - 北京, 1982. -23-87页) (на кит. яз.) / Ху Чжаолян. - Пекин : Изд-во Пекинского университета, 1982. - С. 23-87.
15. Чжан Вэй. Анализ влияния культуры региона на его экономическое развитие $=$ 张玮. 区域文 化对区域经济的影响分析 / 张玮 // 特区经济.2006. - 2 期. - 页 292-297) (на кит. яз.) / Чжан Вэй, Ли Сяоянь, Чжоу Чжэньхуа // Экономика особых районов. - 2006. - № 2. - С. 292-297.

16. Чэнь Цзунсин. Введение в региональную науку = 陈宗兴. 区域科学导论 / 陈宗兴. 西安: 西北大学, 1991. -603 页) (на кит. яз.) / Чэнь Цзунсин. - Сиань : Изд-во Северо-Западного университета, 1991. -603 с.

17. Чян Лэсян. Влияние географической среды на социально-экономическое развитие $=$ 钱乐祥. 地理环境对鲁西经济社会发展的影响-以聊城 地区为例 / 钱乐祥 // 河南大学学报(自然科 学版). - 1992. - 4 期. - 页 61-64) (на кит. яз.) / Чян Лэсян // Издание Хэнаньского университета. Естественные науки. - 1992. - № 4. - С. 61-64.

18. Шэн Сунчэн. Анализ тенденции изменения в уровнях экономического развития регионов = 盛松成. 区域经济差距趋势分析/盛松成, 石春华. - 北京: 北京大学, 2004.-140 页) (на кит. яз.) /Шэн Сунчэн, Ши Чюньхуа. - Пекин : Изд-во Пекинского университета, 2004. - 140 с.

19. Ян Юйян. Экономическая география, пространственная экономика и региональная экономика 杨吾扬. 经济地理学、空间经济学与区域经济学 /杨吾扬 // 地理学报. - 1992. - 6 期. - 页561-569) (на кит. яз.) / Ян Юйян // Географический журнал. 1992. - № 6. - С. 561-569.

20. Banfield, E. The Moral Basis of a Backward Society / E. Banfield. - Chicago : The Free Press, 1958. $-103 \mathrm{p}$.

21. Christaller, W. Central Places in Southern Germany. Englewood Cliffs / W. Christaller. - N. J. : Prentice-Hall, 1966. - $230 \mathrm{p}$.

22. Denison, E. F. The Sources of Economic Growth in the United States and the Alternatives Before US / E. F. Denison. - New York : Committee for Economic Development, Supplementary Paper No. 13, 1962. $-308 \mathrm{p}$.

23. Isard, W. Introduction to regional science /W. Isard. -Englewood Cliffs : Prentice-Hall, 1975.-506 p.

24. Kaldor,N.AModel ofEconomic Growth/N. Kaldor // Economic Journal. - 1957. - Vol. 67. -P. 591-624.

25. Launhardt, W. MathematischeBegriindung der Volkswirtschaftslehre / W. Launhardt. - Leipzig : B.G. Teubner, $1885 .-216 \mathrm{p}$.

26. Yehua, Weil. Analyzing Regional Inequality in Post-Mao China in a GIS Environment / Weil Yehua, Yu Dantin // Eurasian Geagraphy and Economics. 2003. - Vol. 7. - P. 514-534.

27. Yehua, Weil. Beyond convergence: space, scale, and Regional Inequality in China / Weil Yehua, Xinyue Ye // Tijdschrift voor Economische en Sociale Geografie. -2009. - Vol. 100. - P. 59-80. 
28. Yehua, Weil. Regional inequality in China / Weil Yehua // Progress in Human Geography. - 1999. Vol. 23. - P. 45-59.

29. Yehua, Weil. Regional Inequality in China: A Case Study in Jiangsu Province / Weil Yehua // Professional Geographer.-2000. - Vol. 52. - P. 455-469.

\section{REFERENCES}

1. Bao Yuan. Reasons for the Imbalance in the Economic Development of China's Regions and Countermeasures. Henan, Publishing House of Henan Teachers' University, 2008. 186 p. (in Chinese).

2. Wang Xuanxuan. Analysis of the Causes of Inequality in the Economic Development of Four Regions of China. Finance Economics, 2009, no. 11, pp. 131-137. (in Chinese).

3. Veber A. Teoriya razmeshcheniya promyshlennosti [The Theory of Industrial Location]. Leningrad; Moscow, Kniga Publ., 1926. 223 p.

4. Da Zhangchao. Theory of Regional Science. Shanghai, Publishing House of East China Pedagogical University, 1991. 159 p. (in Chinese).

5. Komissina I.N. Nauchnye $i$ analiticheskie tsentry Kitaya [Scientific and Analytical Centers of China]. Moscow, RISI Publ., 2012. 265 p.

6. Ljosh A. Prostranstvennaya organizatsiya khozyaystva [The Spatial Organization of the Economy]. Moscow, Nauka Publ., 2007. 664 p.

7. Li Zhongyi. Analysis of the Causes of China's Unequal Economic Development. Historical Descriptions of Heilongjiang Province, 2009, no. 18, pp. 121-122. (in Chinese).

8. Luo Yu, He Qing, Xue Chang. The Impact of the Rule of Law on China's Economic Development. Economic studies, 2016, no. 7, pp. 119-124. (in Chinese).

9. Lu Zunhua, Ma Chongming, Shi Jianping. Dynamic Analysis of Economic Inequality in China's Regions. Bulletin of Guangdong University on Economic Management, 2001, no. 1, pp. 4-15. (in Chinese).

10. Mi Juan, Su Xingyu. Analysis of the Factors of Economic Growth in the Regions, as well as Its Differences. The Study of Productive Forces, 2012, no. 9, pp. 18-22. (in Chinese).

11. Xu Yueqing, Li Shuangcheng. Dynamic Analysis of Unequal Economic Development in Three Regions of China. Beijing, Publishing house of Beijing University, 2004. 144 p. (in Chinese).

12. Wu Peng, He Chin. The Idea of Shared Prosperity and Uneven Development of China's Regions. China Academic Journal Electronic Publishing House, 2012, pp. 10-12. URL: http:// www.doc88.com/p-904283055840.html (in Chinese) (accessed 21 June 2017).
13. Hu Zhaoliang. Regional Research and Development. Beijing, Publishing House of Beijing University, 1985.97 p. (in Chinese).

14. $\mathrm{Hu}$ Zhaoliang. Characteristics of the Influence of Geographical Location. Beijing, Publishing House of Beijing University, 1982. 87 p. (in Chinese)

15. Zhang Wei, Li Syaoang, Zhou Zhenhua. Analysis of the Influence of Regional Culture on Its Economic Development. Economy of special areas, 2006, no. 2, pp. 292-297. (in Chinese).

16. Chen Zongxing. Introduction to Regional Science. Xian, Publishing House of Northwestern University, 1991. 603 p. (in Chinese).

17. Qian Lexiang. Influence of Geographical Environment on Social and Economic Development. Edition of Henan University. Natural Sciences, 1992, no. 4, pp. 61-64. (in Chinese).

18. Sheng Songcheng, Shi Chunhua. Analysis of Trends in the Levels of Economic Development of the Regions. Beijing, Publishing House of Beijing University, 2004. 140 p. (in Chinese).

19. Yang Wuyang. Economic Geography, Spatial Economy and Regional Economy. Geographical journal, 1992, no. 6, pp. 561-569. (in Chinese).

20. Banfield E. The Moral Basis of a Backward Society. Chicago, The Free Press, 1958. 103 p.

21. Christaller W. Central Places in Southern Germany. Englewood Cliffs; N.J., Prentice-Hall, $1966.230 \mathrm{p}$.

22. Denison E.F. The Sources of Economic Growth in the United States and the Alternatives Before US. New York, Committee for Economic Development, Supplementary Paper No. 13, 1962. 308 p.

23. Isard W. Introduction to Regional Science. Englewood Cliffs, Prentice-Hall, 1975. 506 p.

24. Kaldor N. A Model of Economic Growth. Economic Journal, 1957, vol. 67, pp. 591-624.

25. Launhardt W. MathematischeBegriindung der Volkswirtschaftslehre. Leipzig, B.G. Teubner, $1885.216 \mathrm{p}$.

26. Yehua Weil, Yu Dantin. Analyzing Regional Inequality in Post-Mao China in a GIS Environment. Eurasian Geagraphy and Economics, 2003, vol. 7, pp. 514-534.

27. Yehua Weil, Xinyue Ye. Beyond Convergence: Space, Scale, and Regional Inequality in China. Tijdschrift voor Economische en Sociale Geografie, 2009, vol. 100, pp. 59-80.

28. Yehua Weil. Regional Inequality in China. Progress in Human Geography, 1999, vol. 23, pp. 45-59.

29 Yehua Weil. Regional Inequality in China: A Case Study in Jiangsu Province. Professional Geographer, 2000, vol. 52, pp. 455-469. 


\section{Information about the Author}

Svetlana B. Makeeva, Candidate of Sciences (History), Associate Professor of Department of Oriental and Asia-Pacific Regional Studies, Irkutsk State University, Lenina St., 8, 664006 Irkutsk, Russian Federation, msbmag9581@yandex.ru, https://orcid.org/0000-0003-2953-0411

\section{Информация об авторе}

Светлана Борисовна Макеева, кандидат исторических наук, доцент кафедры востоковедения и регионоведения АТР, Иркутский государственный университет, ул. Ленина, 8, 664006 г. Иркутск, Российская Федерация, msbmag9581@yandex.ru, https://orcid.org/0000-0003-2953-0411 